\title{
UTILITY MAXIMISATION AS A PATHWAY FOR MAXIMISATION OF HAPPINESS
}

Siddhartha Mitra*

Department of Economics, Jadavpur University

Kolkata, India

DOI: 10.7906/indecs.11.3.6

Received: 27 March 2013.

Brief report

Accepted: 7 July 2013.

\section{ABSTRACT}

It is hypothesized that pursuit of human happiness is carried out through adaptive change in utility functions by drawing lessons from, in an ex-post manner, the effect of short run utility maximizing choices on utility possibilities. A reference frame for future research is designed to check the truth of this hypothesis which would draw on the methodology already in use for conducting happiness surveys.

\section{KEY WORDS}

happiness, utility maximisation

\section{CLASSIFICATION}

JEL: $\quad$ I15 


\section{INTRODUCTION}

\section{PROLOGUE: CONTRADICTIONS AND CONNECTIONS BETWEEN UTILITY MAXIMIZATION AND THE PURSUIT OF HAPPINESS}

Utility can be defined in two ways (the discussion of these two types that follows is based on [1]). The first one corresponds to 'decision utility' or 'wantability' - an ex-ante ranking of preferences used to make choices. Utility is revealed by actual choice in this case - when an individual faced with a range of options actually makes a choice then that choice is revealed to be utility maximising over the mentioned range. The second notion of utility is in the nature of 'experienced utility' and was formulated by utilitarians such as Jeremy Bentham. They claimed that this notion - which disappeared from practical use by the beginning of the $20^{\text {th }}$ century - was very similar to happiness. Edgeworth's Mathematical Psychics [2] even went so far as to define happiness as the temporal integral of momentary experienced utility.

But is our own conception of utility immutable during our lifetime? Or does it exhibit dynamism as we flounder or progress in the achievement of happiness? I feel that such questions are worth answering if the process of 'utility maximisation' - one that economists lay so much stress on - is to be linked to the pursuit of happiness, which is arguably the objective of human life.

The objective of this paper is to sketch out a research agenda that would add greater insight to our understanding regarding whether, to what extent and how the process of utility maximisation is linked to the pursuit of happiness. In what follows we show through illustrations/thought experiments that evolutionary mechanisms might possibly link utility maximisation and happiness. By 'evolution' we do not refer here to the evolution of a population cohort or species over time. Rather we refer to the evolution of an individual (his behavioural patterns and therefore his preferences) over his life time. Given the possibility of the mentioned linkages, we design a research agenda to find out whether such mechanisms are actually active and significant in reality.

A possible hypothesis is that an individual might change his preference ordering in response to the wisdom gathered from the cumulative impact on his happiness of the interaction among his own 'momentary utility maximizing choices', the reactions of the outside world to the mentioned choices, and external circumstances which affect the individual but do not arise from his own actions. When viewed in this manner, the very process of utility maximization results in a tuning of utility functions in the pursuit of happiness. Assuming a broad positive correlation between rankings of 'wantability' and experienced utility and neglecting factors that might drive a wedge between these ${ }^{1}$, the rankings of experienced utility from various choices would also change over the course of a person's lifetime.

\section{THE POSSIBILITY THAT UTILITY MAXIMISATION MAY ALSO BE A MEANS TO AN END: A DEEPER EXPLORATION}

Economists generally view utility maximisation as an end in itself. But can we look upon it as an evolutionary process which is a means to an end? To put things very simply, there is this concept of happiness - we can feel it but often we do not know what drives its increase or decrease, at least during the beginning of our lives or even our youth. What satisfies us momentarily is however easier to choose - when presented with a menu in a restaurant we can pick out the food item which offers us the best possible satisfaction within our budget; when given a choice of practising on the piano or going out for a movie with friends we may again find it quite easy to make the choice which gives us higher momentary experienced utility. 
But here lies the trick. If we keep our utility functions fixed, the maximisation of these not only affects experienced utility but in conjunction with external circumstances and the reactions of others and 'nature' to our actions affect our utility possibilities in the future, sometimes adversely so - as examples would point out. But if, as Edgeworth pointed out, happiness is the temporal integral of experienced utilities then utility maximisation on the basis of an unchanged utility function is not possibly the best means for maximising happiness or even for obtaining satisfactory happiness outcomes.

Let us give some examples at this stage to show that utility maximisation on the basis of a given utility function might lead an individual to a very unhappy state of affairs.

Example 1: In period 1 a person might find it better from the point of view of maximising immediate utility to hang out with his friends after school instead of learning to play the piano or cultivating a reading habit. Imagine that he or his friends have to move to another city at the end of period 1. Now consider period 2 as the present. Had the person devoted some time to playing the piano or cultivating a reading habit in period 1 at the expense of time spent in hanging out with his friends, in the present he would have recourse to an activity from which he could derive satisfaction in solitude by being absorbed in it. But he does not and neither does he have access to close friends. He therefore experiences very low levels of immediate utility even if he is a utility maximizer. In other words, he becomes a very unhappy person.

Example 2: A person might lead a very bohemian lifestyle in period 1 - working hard and playing hard. He might have numerous girl friends at the same time; indulge in late night parties characterised by heavy drinking; and at the same time make additions to his wealth by working quite hard in office. Over a short period of time (i.e. throughout period 1) these might feel like the right choices as the momentary satisfaction experienced would be very high. But even if we assume that immediate satisfaction is maximized, gradually such behaviour might take a toll on physical and mental health, which from the point of view of the individual might affect his ability to experience pleasure as well as be absorbed in activities in period 2 . There also might be reactions to his behaviour in period 1 in period 2 - his numerous girl friends, for example, when they find out about each other and his lack of loyalty might feel malice towards him and their reactions might have a rebound effect on his mental health. Positive feelings such as courage, optimism and hope might take a beating in period 2 .

Here we are assuming that individuals cannot display perfect foresight in maximising lifetime utility as they cannot factor in external reactions to their own actions, the impact of their actions on their own sensory systems, and above all external circumstances which affect their utility possibilities in conjunction with the previous two factors. If utility depends only on the temporal income and wealth profile which in turn depends on allocation of time among various competing uses alone then perfect foresight regarding income streams flowing from various alternative temporal allocative profiles - an assumption which might approximate reality - could be used for accurate dynamic utility optimisation. But in this paper we are looking at a much broader conception of utility, with greater applicability to overall human behaviour, which extends to the emotional space. Given that no unique correspondence can be drawn between the level of income or wealth and the vector of emotions, perfect foresight might not be very easily applicable in regard to this broader conception of utility.

To summarise, once we consider utility functions that depend on factors other than income or wealth, perfect or 'close to perfect' foresight about utility profiles would not be possible in reality. In such cases, past history about actions taken, reactions of the types mentioned above to these, and utility levels experienced could be useful for the evolution of utility functions. And if utility functions are to evolve, surely they would evolve such that their maximisation leads us to greater happiness. 
The above examples establish that short term utility maximisation on the basis of a fixed utility function might not maximise the sum of utilities i.e. happiness. In fact, such maximization can lead to very low levels of experienced happiness. In Example 1, one can imagine that if the person concerned had even devoted an hour daily in the initial period to practising on the piano and therefore spent an hour less in hanging out with his friends, his utility in the initial period would have gone down by an amount far less than the increase in utility caused by the recourse to a pleasurable activity in the second period. Not only would the sum of utilities occurring through utility maximisation be far lower than that occurring through a non 'utility maximising' choice, utility maximisation in the first period leads the person concerned to a choice set in the second period where the highest level of utility attainable is low ${ }^{2}$.

Note here that the individual does not foresee the change in external circumstances i.e. his friends going away. In other words, the 'utility maximisation' we refer to here is utility maximisation without that kind of foresight. Similarly, in Example 2 the utility maximisation followed by individual 2 does not take note of adverse biological reactions of his own body to lack of sleep and alcohol; and possible reactions of others (his numerous girl friends in this case) in period 2 to his actions towards them in period 1. If utility maximisation displays such foresight, which is assumed to be absent in Examples 1 and 2, then utility maximisation by the individual is consistent with the maximisation of the temporal integral of utilities i.e. happiness in the sense of Edgeworth.

Casual empiricism seems to suggest that such foresight does not exist to the extent that it can be deemed as 'perfect' or even nearly so. However, to what extent it exists is something which deserves evaluation through research. To the extent it does not exist, the following research question is also of great significance as mentioned before: do individuals tune their utility functions in response to attained levels of happiness under varied circumstances and is such tuning significant?

In the next section we look at the newly emerging field of positive psychology. This field has outlined the components of happiness. We explore these components and outline what 'lack of foresight' and 'tuning of utility functions' mean in terms of the vocabulary of positive psychology.

\section{POSITIVE PSYCHOLOGY AND THE INSIGHTS OFFERED ABOUT THE EVOLUTIONARY NATURE OF UTILITY MAXIMIZATION}

Quite recently, study of how changes in one's life style can affect one's level of well being has become the preoccupation of a fast emerging field of clinical psychology which goes by the label of 'positive psychology' (see [3] for an introduction to positive psychology). Practitioners of positive psychology have defined happiness as being made up of three components: positive emotions (i.e. feelings of forgiveness, contentment and satisfaction with reference to the past; savouring of pleasures, kindness, and compassion in the present; and courage and optimism for the future); the ability to be completely absorbed in an activity often referred to as 'flow' (for example, professional activities such as teaching, pleasurable activities such as listening to music, and household chores such as repairing a bicycle or decorating one's house for a festival); and the satisfaction derived in working for a higher good which is above one's narrow self interest [4].

In terms of the above concepts, part of the deviation from perfect foresight might be accounted for by the failure to incorporate, while choosing a vector of actions from the set of possible action vectors, the impact of present actions on the components of future happiness such as the attainment of flow; and retrospective emotions such as contentment and satisfaction. Such deviation implies that an individual defines his own utility in terms of current emotions or even more narrowly, the savouring of pleasures. 
But while such deviations from perfect foresight do result in deviations from optimal happiness, adaptive mechanisms which correct for such deviation from optimality are not ruled out. Thus, an important question is whether it is possible that over time our utility functions evolve to incorporate hitherto ignored components of happiness through 'learning by doing'. For example, a person who initially incorporates only the savouring of pleasures in his utility function might incorporate 'flow' in it or give importance to emotions relating to the past as a result of life's experiences or by learning from the actions of others in similar circumstances. There are others who might incorporate the satisfaction gained from social service.

Let us refer back to our examples. In Example 2, we can see that an individual ends up impairing his material and physical health through the static maximisation of a fixed utility function. This can be attributed to a lack of foresight about how his own utility maximising choices (late night parties and heavy drinking in combination with self inflicted work related strains) affect his sensory systems (his knowledge of the intricacies of human biology might be poor) and about the reactions of the outside world (for example, those of his numerous girl friends whom he dated at the same time) to his actions. Thus, the mentioned process of utility maximisation could take him to a rock bottom level of happiness. When that rock bottom level of happiness is reached we can hypothesize that a process of introspection is stimulated as survival instincts of the individual take over to bring back his levels of happiness to respectable levels. Having experienced the consequences of his actions, the cause and effect relationships underlying 'happiness outcomes' become clearer. For example, he realises the disastrous consequences of having multiple girl friends at the same time and becomes devoted to a single partner; he realises that late nights and the alcohol consumed at late night parties has resulted in a numbing of the senses whose reversal would require a drastic change in behaviour patterns no more late night parties etc. Having reached this rock bottom level of happiness he may seek counselling and find solace in pursuing a hobby such as playing the piano or social service.

What is being emphasised here is that a hard lesson is learnt by the individual in question and this convinces him to change his habits so radically that in the future he experiences very high levels of happiness. The causal link therefore is as follows: nature of utility function that causes him to leas a bohemian strenuous life $\rightarrow$ rocks bottom levels of happiness $\rightarrow$ drastic change in lifestyle $\rightarrow$ very high levels of happiness.

What is interesting in this example is that the utility function in the beginning is very important. For had that not existed the temporal utility profile leading to rock bottom levels of happiness would not have been experienced and the radical change in utility function and thus behaviour and experienced happiness would not have been brought about. Many individuals probably lead 'regular' or 'ordinary' or 'uninteresting lives' and in that sense are quite different from the portrayed individual. But because their happiness does not reach rock bottom they do not feel the need to introspect on their behaviour. And therefore they continue to be averagely happy throughout their life.

In Example 1, a similar learning by doing might be experienced. The individual initially has a utility function in which savouring of present pleasures is important. He also displays very poor foresight as to how actions in period 1 can help in the attainment of 'flow' in period 2 and thus augment his happiness - he thus fails to derive little satisfaction in period 1 from such activities. But the maximisation of such a utility function in conjunction with change in circumstances (his close friends moving away) lead to very poor utility possibilities in period 2 . His happiness reaching rock bottom levels again prompts introspection as to whether an alternative course of action could have been better. The possible gains from alternative courses of action, such as those that correspond to investments in 'flow', would become evident if the experiences of others are closely examined or counselling sought. Such 
introspection and examination might lead to a change in life style - a balance is therefore probably struck between flow promoting activities and social interaction.

Note that the inability to foresee a change in external circumstances (such as friends moving away) also constitutes a deviation from perfect foresight. Here, too, a different sort of adaptation might come into play - as an individual experiences different circumstances he might be better able to evaluate the range of variation of these and make choices which would yield satisfactory outcomes in regard to happiness under different possible circumstances. For example, an individual who hones his skills at social interaction and in a hobby ensures that he ends up at least reasonably happy irrespective of whether chances for social interaction present themselves or not, and at the same time ensures that he makes full use of these happiness augmenting opportunities when they do.

\section{IN CONCLUSION: A RESEARCH AGENDA FOR THE FUTURE}

Recent experimental research in economics on happiness seeks to measure the level of happiness in people by asking them to choose a non-negative integer $i$, on a $n$ point scale, which signifies the level of agreement with an appropriate statement, such that a higher value of $i$ implies a higher level of happiness. Thus, what is presented through the statement is an ordinal scale of happiness with the individual asked to place himself on it.

A prominent example of the above is the single-item question on a three-point scale in [5] which asks: "Taken all together, how would you say things are these days-would you say that you are very happy, pretty happy, or not too happy?" In the World Values Survey, life satisfaction is assessed on a scale from one (dissatisfied) to ten (satisfied) [6], which asks: "All things considered, how satisfied are you with your life as a whole these days?"

Such surveys have been shown to be reasonably accurate. Following [7] we can claim that errors in people's responses are random and cancel out due to the law of large numbers. This also holds true for errors caused by the order of questions, the wording of questions, and actual mood. In regard to the research problems posed above we can ask the following specific research questions: Consider those individuals who have transited from very low levels of happiness to high levels of happiness as revealed by longitudinal surveys. Is the proportion of such individuals in the population significantly high? Is such a transition a result of a change in lifestyles to a significant extent or can it be explained primarily by a change in socio-economic determinants such as income, marital status etc; or can it be attributed to the interaction between changes in socio-economic factors and lifestyle or the former emerging from the latter?

In regard to the first question we need to define what constitutes a significant jump in happiness. For example, we may say that any person who has recorded a 2 point increase on a 3 point ordinal scale of happiness or a 6 point increase on a 10 point ordinal scale of happiness can be deemed as having registered a significant increase in happiness. The numbers 2 and 6 are just illustrative. Researchers need to devote adequate thought to these numbers.

In regard to the second question, it deserves mention that a change in lifestyle and socioeconomic determinants might be quite correlated. For example, a person who learns through life's experiences will change his lifestyle with age. If we regress happiness on age we may expect a positive effect though this is the same as that provided by the change in lifestyle stimulated by life's experiences (or in more technical terms the 'evolution of the utility function'). The same may be true of marital status [8]. Exhaustive case studies of the persons who have experienced significant increases in happiness are therefore required to single out the root cause of this increase - lessons learnt from life and the consequent conscious change 
in lifestyles which might or might not result in any change in socio-economic variables under study; or a change in socio-economic variables that has got nothing to do with any conscious design to change one's lifestyle.

\section{REMARKS}

${ }^{1}$ Kahneman and Thaler [1] make the point that the choices that maximize 'wantability' might not be optimal from the point of view of 'experienced utility'. They specifically elaborate on the nature of change in circumstances from-to, where the former is the point of time at which choices are made and the latter is the point of time at which outcomes of choice are experienced, such as change in emotional or motivational state of the agent; and change in the aspects of the outcome on which there is focus at these two points of time (say aesthetics of the purchased item versus its functional use).

${ }^{2}$ In [3] a similar argument is made: under many circumstances it might be better to withhold maximization of immediate enjoyment of pleasures at a given point of time.

\section{REFERENCES}

[1] Kahneman, D. and Thaler, R.H.: Anomalies: Utility Maximization and Experienced Utility. Journal of Economic Perspectives 20(1), 221-234, 2006, http://dx.doi.org/10.1257/089533006776526076,

[2] Edgeworth, F.Y.: Mathematical Psychics.

C. K. Paul, London, 1881,

[3] Seligman, M.E.P and Csikszentmihalyi, M.: Positive psychology. An introduction. American Psychologist 55(1), 5-14, 2000, http://dx.doi.org/10.1037/0003-066X.55.1.5,

[4] Seligman, M.E.P.; Parks, A.C. and Steen, T.: A Balanced Psychology and a Full Life. Philosophical Transactions of the Royal Society B 359(1449), 1379-1381, 2004, http://dx.doi.org/10.1098/rstb.2004.1513,

[5] Davis, J.A.; Smith, T.W. and Marsden. P.V.: General Social Survey, 1972-2000. Cumulative Codebook.

National Opinion Research Center, Chicago, 2001,

[6] Inglehart, R.F.: Culture Shift in Advanced Industrial Society. Princeton University Press, Princeton, 1990,

[7] Frey, B.S. and Stutzer, A.: What Can Economists Learn from Happiness Research? Journal of Economic Literature 40(2), 402-435, 2002, http://dx.doi.org/10.1257/002205102320161320,

[8] Easterlin, R.A.: Explaining happiness. PNAS 100(19), 11176-11183, 2003, http://dx.doi.org/10.1073/pnas.1633144100. 


\section{MAKSIMIZIRANJE KORISNOSTI KAO NAČIN MAKSIMIZIRANJA SREĆE}

S. Mitra

Ekonomski odsjek, Sveučilište Jadavpur

Kolkata, India

\section{SAŽETAK}

Postavljena je hipoteza kako se ljudska potraga za srećom odvija adaptivnim promjenama funkcije korisnosti izvlačenjem lekcija na temelju učinaka kratkoročnih izbora maksimiziranja korisnosti među mogućim ishodima. Za provjeru hipoteze postavljen je okvir budućih istraživanja koja će se koristiti metodologiju koja se već koristi u provođenju istraživanja sreće.

\section{KLJUČNE RIJEČı}

sreća, maksimiziranje korisnosti 